\title{
Morfologia de frutos, sementes e plântulas de nove espécies de Protium Burm. f. (Burseraceae) da Amazônia Central, Brasil
}

\author{
Maria de Fátima Figueiredo Melo ${ }^{1,3}$, Sheron Torres de Macedo ${ }^{1}$ e Douglas Charles Daly ${ }^{2}$
}

Recebido em 12/12/2005. Aceito em 13/11/2006

\begin{abstract}
RESUMO - (Morfologia de frutos, sementes e plântulas de nove espécies de Protium Burm.f. (Burseraceae) da Amazônia Central, Brasil). O presente estudo teve como objetivo descrever para nove espécies de Protium, a morfologia desde a germinação até a formação de plântulas, além de caracterizar frutos e sementes e avaliar a utilidade destes caracteres na sistemática do grupo. Os frutos foram coletados na Reserva Florestal Adolpho Ducke em dezembro/2004, abril/2005 e janeiro/2006. Os frutos são deiscentes, normalmente com 1-3 lóculos desenvolvidos. Os pirênios são ovóides a elipsóides, com a superfície diferenciada em torno da cicatriz funicular. A maioria das espécies apresentou germinação hipógea e criptocotiledonar, enquanto $P$. gallosum e $P$. apiculatum são epígeas e fanerocotiledonares. Os caracteres morfológicos mais relevantes para a delimitação das espécies de Protium foram encontrados, principalmente, na coloração, forma e superfície do fruto e pirênio, e na forma e textura dos eofilos. Além disso, o conjunto de caracteres com base na composição, margem e ápice dos eofilos, tipo de germinação e morfologia dos cotilédones não só auxiliou nas delimitações específicas, como pode subsidiar futuros estudos filogenéticos.
\end{abstract}

Palavras-chave: morfologia, germinação, sistemática

ABSTRACT - (Fruit, seed and seedling morphology of nine species of Protium Burm.f. (Burseraceae) from Central Amazonia, Brazil). We describe the morphology of nine species of Protium, ranging from germination to seedling formation, and characterize gross morphology of fruits and seeds in order to assess the usefulness of these characters for systematics of the group. Fruits were collected in the Adolpho Ducke Forest Reserve in December/2004, April/2005 and January/2006. The fruits are dehiscent and usually 1-3 locules develop. The pyrenes are ovoid to ellipsoid, and the surface is differentiated around the funicle scar. Most species had hypogeal, cryptocotylar germination, but $P$. gallosum and $P$. apiculatum had epigeal, fanerocotylar germination. The most relevant morphological characters for distinguishing these species are color, shape and surface of the fruit and pyrene, and form and texture of the eophylls. Furthermore, the series of characters based on composition, margin and apex of the eophylls, type of germination, and cotyledon morphology helped to distinguish the species and will serve to support future phylogenetic studies.

Key words: morphology, germination, systematics

\section{Introdução}

O manejo, a conservação e a reconstituição de florestas tropicais dependem da compreensão da regeneração e outros processos ecológicos que, por sua vez, estão atrelados à realização de estudos que permitam a precisa identificação das espécies vegetais a partir de suas fases juvenis (Oliveira 2001). Moreira \& Moreira (1996) afirmam que as informações sobre as características da germinação de espécies florestais representam a base da silvicultura e do manejo sustentado. Isso porque, os estudos morfológicos de sementes permitem a determinação das espécies existentes nos bancos de sementes do solo e a identificação de espécies florestais na fase jovem, contribuindo para a compreensão da regeneração natural e sucessão em ecossistemas florestais (Kuniyoshi 1983; Beltrati 1984; 1992). Araújo et al. (2004) afirmam que, tanto para espécies florestais nativas como para exóticas, há uma carência de estudos sobre morfologia de sementes e plântulas.

Os estudos sobre a morfologia de plântulas têm aumentado nos últimos anos com o propósito de ampliar o conhecimento sobre as espécies, entretanto as

\footnotetext{
1 Instituto Nacional de Pesquisas da Amazônia, Coordenação de Pesquisas em Botânica, Av. André Araújo 2936, 69083-000 Manaus, AM, Brasil

2 New York Botanical Garden, Southern Boulevard, 200, Bronx, 10458-5126 New York, Estados Unidos (ddaly@nybg.org)

3 Autor para correspondência: ffmelo@inpa.gov.br
} 
plântulas não têm sido utilizadas pela sistemática, uma vez que, em geral, apenas os caracteres vegetativos e sexuais da planta adulta são considerados.

Para Oliveira (1993), o conhecimento morfológico da plântula permite caracterizar famílias, gêneros e até espécies e tem sido aplicado no inventário florestal de muitas regiões de clima temperado e tropical. Além disso, os trabalhos sobre a germinação de sementes com ênfase na descrição de plântula normal e anormal contribuem na interpretação e padronização dos testes de germinação através do conhecimento de cada espécie.

Os resultados obtidos de estudos sobre frutos e sementes podem ser uma ferramenta interessante capaz de acrescentar informações à sistemática tradicional e ao mesmo tempo podem fornecer subsídios para delimitações específicas. Lima (1985) utilizou caracteres morfológicos de frutos, sementes e embriões de 15 gêneros da tribo Mimoseae Bronn (Leguminosae) ocorrentes no Brasil, e concluiu que os resultados fornecem informações importantes na sistemática dos gêneros.

Outro fator importante que vale a pena ressaltar, refere-se ao fato dos frutos e sementes serem um recurso facilmente observável e, juntamente com as plântulas, sofrerem pouca plasticidade fenotípica, sendo, por isso, considerado de elevada importância taxonômica. As características do hipocótilo, tais como indumento, cor e ornamentação específica, são úteis na delimitação de gênero e na identificação a nível de espécie (Oliveira 1993).

Protium Burm.f., conhecido vulgarmente como breu na Amazônia brasileira, destaca-se pela diversidade de espécies na Amazônia, com aproximadamente 73 espécies ocorrentes, sendo ca. 42 endêmicas da região (Daly 1992). Aproximadamente, 37 espécies de Protium foram confirmadas na Amazônia Central, através de levantamentos florísticos realizados na década de 90, por Nee (1995) e Ribeiro et al. (1999). Desde os primeiros inventários florestais realizados na Amazônia, as Burseraceae têm sido reconhecidas como altamente importantes, mas difíceis de diferenciar (Black et al. 1950). Este fenômeno em Protium e em outros gêneros como Virola (Myristicicaceae), talvez seja resultado de uma radiação evolutiva recente nestes grupos, como aparentemente foi o caso no gênero Inga (Richardson et al. 2001).

A resina das espécies do gênero é utilizada, pela população local, para iluminação e para calafetar canoas, além do uso no preparo da tinta ou verniz preto
(Ribeiro et al. 1999; Siqueira 1991). As folhas são usadas por serem aromáticas e, em algumas espécies, os frutos são comestíveis (Killeen et al. 1993). Além disso, partes das plantas (cascas e folhas) são reconhecidas na medicina popular como antiinflamatório, antitumoral e adstringente (Susunaga 1996).

Praticamente não existem estudos sobre morfologia de frutos, pirênios e plântulas de espécies de Protium e os trabalhos que existem ainda são incipientes. Os poucos trabalhos realizados sobre o desenvolvimento pós-seminal da família Burseraceae foram tratados por Duke (1969), ao descrever cerca de duzentas espécies florestais do Canal do Panamá, e por Ricardi (1996) que aborda a morfologia dos cotilédones de plântulas da família Burseraceae presentes na Venezuela. Recentemente, Ferraz et al. (2004) descreveram a morfologia dos frutos e sementes de três espécies do gênero Protium ocorrentes na Amazônia Central, comparando a morfologia das plântulas com as características dos indivíduos adultos.

Face à carência de estudos morfológicos de sementes e plântulas de Burseraceae o presente trabalho teve como objetivo descrever os caracteres morfológicos de sementes e plântulas, além de fornecer informações sobre o tipo de germinação e descrever a morfologia de frutos para fins práticos de identificação.

\section{Material e métodos}

Os frutos de Protium foram coletados, no período de dezembro/2004 a abril/2005 e janeiro/2006, de árvores localizadas na Reserva Florestal Adolpho Ducke (km 26 da AM-010), pertencente ao Instituto de Pesquisas da Amazônia - INPA, com uma área de $100 \mathrm{~km}^{2}$, situada na periferia de Manaus. O clima da região é do tipo $A f i$ de Köppen, com temperatura média de $26^{\circ} \mathrm{C}$ (mínima $19^{\circ} \mathrm{C}$ e máxima $39^{\circ} \mathrm{C}$ ) e precipitação anual que varia de 1.800 a $2.800 \mathrm{~mm}$ (Luizão \& Vasconcelos 2005).

O estudo foi desenvolvido no Laboratório de Taxonomia Vegetal da Coordenação de Pesquisas em Botânica (CPBO), do INPA. O experimento foi montado a céu aberto em espaço localizado próximo ao laboratório.

Os dados biométricos dos frutos e pirênios foram obtidos através de 25 unidades selecionadas aleatoriamente, medindo-se o comprimento, largura e espessura dos frutos e pirênios com o auxílio de um paquímetro digital de marca Mitutoyo com precisão de $0.1 \mathrm{~mm}$. Após a realização do teste biométrico dos frutos, os pirênios foram beneficiados manualmente 
por maceração ou debulhamento até a completa remoção do arilóide. Para cada uma das variáveis estudadas foram calculados a média aritmética e o desvio padrão, e determinados os valores mínimos e máximos.

$\mathrm{Na}$ descrição morfológica dos frutos foram observados tipo, coloração, consistência do pericarpo, número de lóculos, dimensões, textura e indumento. Para a descrição morfológica dos pirênios, foram observadas a forma, as características superficiais (cor, textura, superfície) e as dimensões. Nesta última levou-se em conta: comprimento $\times$ largura $\times$ espessura, além da espessura do endocarpo.

Para o acompanhamento da germinação foram utilizados 30 pirênios para cada espécie, que foram colocados em bandejas plásticas com dimensões de $30 \times 20 \times 6 \mathrm{~cm}$, tendo como substrato uma camada de areia lavada e uma camada de vermiculita. Considerou-se germinação o período compreendido desde a emissão da raiz primária até a emergência do epicótilo. Foi analisado também o tipo de germinação.

As plântulas que se apresentaram mais vigorosas foram utilizadas para a descrição morfológica. Considerou-se plântula a fase em que os eofilos (as primeiras estruturas laminares) apresentavam-se totalmente formados. Os elementos vegetativos descritos e ilustrados na fase de plântula foram: raiz (principal e secundária): forma, cor e superfície; coleto: forma, cor e superfície; hipocótilo: forma, cor e superfície; eofilos: filotaxia, forma, superfície, cor, pecíolo e gemas.

As observações e fotografias foram feitas com auxílio de máquina digital e estereomicroscópio, para melhor visualização das estruturas e indumento.

A terminologia empregada está de acordo com os trabalhos de Lawrence (1951); Duke (1969); Radford et al. (1974); Beltrati (1992); Oliveira (1993); Barroso et al. (1999) e Vidal \& Vidal (2000).

\section{Resultados}

Protium polybotryum (Turcz.) Engl. ssp. blackii (Swart) Daly

Morfologia do fruto e pirênio - Os frutos são elipsóides, $25-29 \times 14-31 \times 14,5-22 \mathrm{~mm}$, com ápice e base arredondados, estipitados quando imaturos, sésseis quando maduros (Fig. 1). São deiscentes, abrindo-se geralmente em 2-3 valvas internamente reticuladas, de coloração creme, esbranquiçada ou rosada; 3-4 lóculos, sendo 1-3 desenvolvidos. Exocarpo sublenhoso, liso, glabrescente, brilhoso, de cor verde quando imaturo, vináceo quando maduro. O mesocarpo é carnoso, delgado, rosado a vermelho intenso; arilóide carnoso, branco a hialino quando em contato com o ar, envolvendo todo o pirênio (Fig. 2). O pirênio é oblongo a ligeiramente ovado (Fig. 3), dorsalmente côncavo, 19-23,5×9,5-12,5×8-10,5 mm, com ápice agudo e base truncada a retusa, superfície irregular, de consistência óssea, áspera, glabra e sem brilho, com espessura do endocarpo ca. de $0,67 \mathrm{~mm}$, coloração verde a castanha com manchas escuras em toda a sua extensão exceto na face ventral, próximo ao ápice, em torno da cicatriz funicular, que apresenta uma região diferenciada, subapical, de coloração castanha e glabra; cicatriz funicular em depressão, arredondada-deltada. Em secção longitudinal, apresenta cotilédones contortuplicados (Fig. 4).

Morfologia da germinação - A germinação é do tipo hipógea, criptocotiledonar. A emissão da raiz ocorre com o rompimento no ápice do pirênio e pode ser observada cerca de 28 dias após a semeadura. A raiz primária apresenta-se cilíndrica, afunilando-se em direção ao ápice, inicialmente creme e glabra. À medida que se desenvolve, a raiz primária torna-se amarelada a marrom. As raízes secundárias são inicialmente amareladas, cilíndricas, delgadas e distribuídas irregularmente ao longo da raiz primária. Coleto inconspícuo. Hipocótilo não desenvolvido ou ausente. Pecíolos cotiledonares bastante reduzidos, lateralmente achatados. Base da lâmina cotiledonar parcialmente exposta, de coloração rosada a verde (Fig. 5).

Morfologia da plântula $-P$. polybotryum ssp. blackii chega à fase de plântula cerca de 42 dias após a semeadura (Fig. 6). Apresenta sistema radicular axial; raiz primária cilíndrica, marrom, glabra; raízes secundárias cilíndricas, ramificadas, marrons a castanhas, distribuídas irregularmente ao longo da raiz primária. Coleto e hipocótilo não distintos. Epicótilo cilíndrico, ereto, longo, ca. $80 \mathrm{~mm}$ de comprimento, marrom-claro a verde-claro (no ápice), glabrescente (Fig. 7). Eofilos dois, simples, opostos, ovados, pêndulos, avermelhados a verdes, membranáceos, ápice caudado, base levemente cordada e margem inteira; nervura principal puberulenta em ambas as faces; pecíolos canaliculados, ca. $1,5 \mathrm{~cm}$ de comprimento, pubescentes próximo da base dos eofilos (Fig. 8-9).

\section{Protium grandifolium Engl.}

Morfologia do fruto e pirênio - Os frutos são globosos 
(Fig. 10), 20,2-24,8×20,2-34,8×19,2-30,3mm, com ápice curvado e base arredondada, com estigma e estilete persistentes. São deiscentes, abrindo-se, em geral, em 2-3 valvas internamente creme e reticuladas. Exocarpo lenticelado (Fig. 11), coriáceo, delgado, semibrilhoso, verde-amarelado, recoberto por pêlos adpressos e esparsos. O mesocarpo é delgado, carnoso, verde-claro a esbranquiçado; arilóide branco, delgado e fibroso, envolvendo o pirênio. O pirênio é globoso, com superfície irregular, 14,4-18,3×13,5-20×12,5-17,5 mm, de consistência subóssea, com ápice agudo e base arredondada e assimétrica (Fig. 12), superfície irregular, opaca, puberulenta, verde-amarelada em toda a sua extensão exceto na parte ventral, em torno da cicatriz funicular, que apresenta uma região diferenciada, esbranquiçada e glabra, ca. 1,18 mm do ápice; cicatriz funicular punctiforme; espessura do endocarpo ca. 0,38 mm. Em secção longitudinal, os cotilédones são contortuplicados (Fig. 13).

Morfologia da germinação - A germinação é do tipo hipógea, criptocotiledonar. A emissão da raiz ocorre com o rompimento do ápice do pirênio e pode ser observada cerca de sete dias após a semeadura. A raiz primária apresenta-se inicialmente cônica, creme e glabra. À medida que se desenvolve, a raiz primária torna-se amarelada. As raízes secundárias são
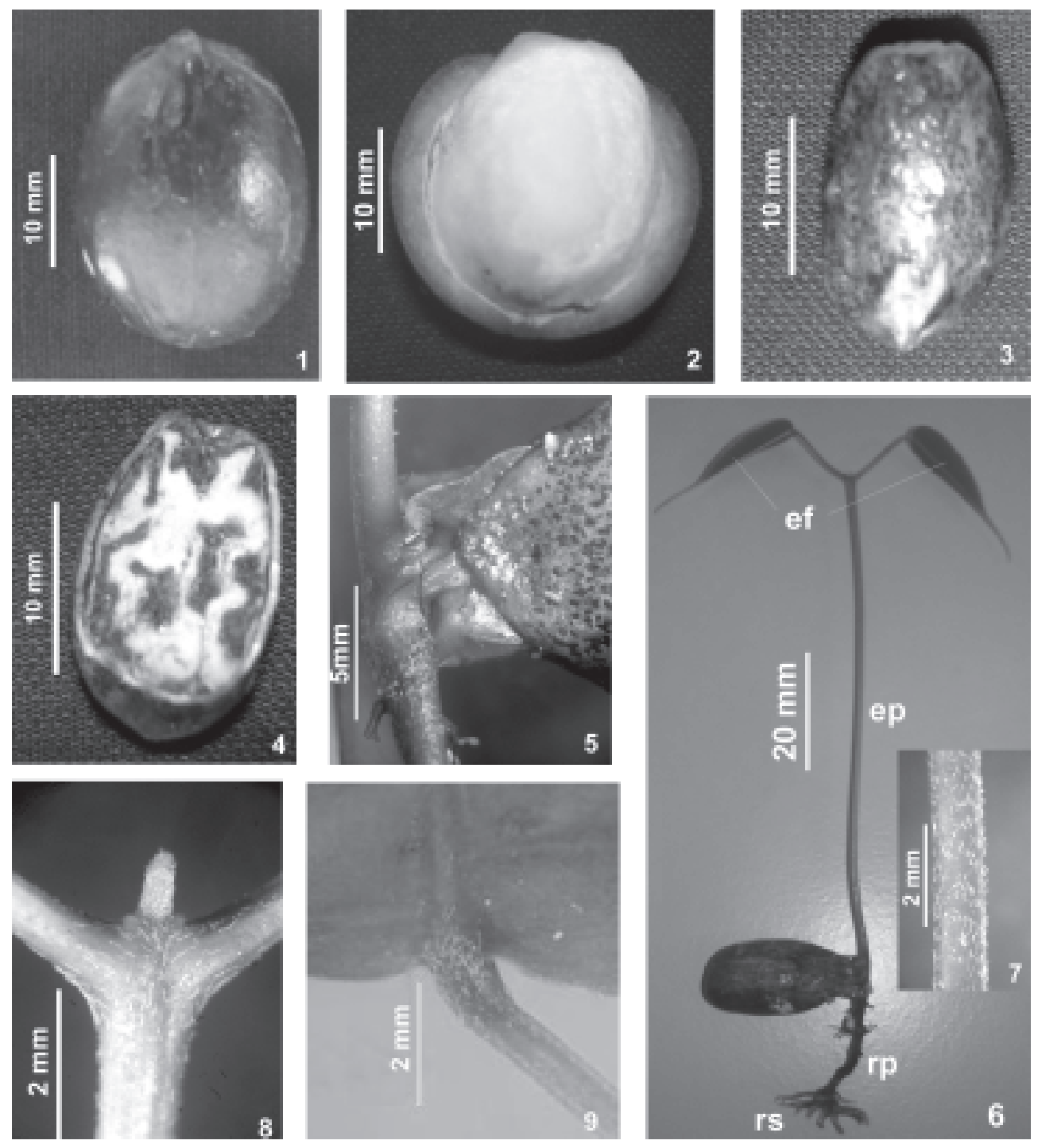

Figuras 1-9. Protium polybotryum (Turcz.) Engl. ssp. blackii (Swartz.) Daly. 1. Fruto maduro. 2. Fruto maduro aberto com detalhe do arilo. 3. Pirênio. 4. Secção longitudinal do pirênio mostrando embrião. 5. Detalhe da plântula na região dos pecíolos cotiledonares. 6. Plântula. 7. Detalhe dos tricomas no epicótilo. 8. Detalhe dos tricomas na plântula nas regiões dos pecíolos e gemas. 9. Detalhe da plântula na região do pecíolo do eófilo. (rp = raiz primária, rs = raízes secundárias, ep = epicótilo, ef = eofilos). 
inicialmente amareladas, cilíndricas, delgadas e se distribuem irregularmente ao longo da raiz primária. $\mathrm{O}$ coleto é linear, pouco evidente. O hipocótilo apresenta-se semi-hipógeo, cilíndrico, espesso, herbáceo, puberulento, creme a rosado (Fig. 14). Pecíolos cotiledonares evidentes, cilíndricos, curtos, $4 \mathrm{~mm}$ de comprimento, glabros. Base da lâmina cotiledonar parcialmente exposta, de coloração verde (Fig. 14).

Morfologia da plântula $-P$. grandifolium chega à fase de plântula cerca de 37 dias após a semeadura (Fig. 15). Apresenta sistema radicular axial; raiz primária espessa, cilíndrica, marrom e glabra; raízes secundárias cilíndricas, não ramificadas, marrons, distribuídas irregularmente ao longo da raiz primária. Coleto linear. O hipocótilo é reduzido, ca. $3 \mathrm{~mm}$ de comprimento, castanho e glabro (Fig. 14). Epicótilo cilíndrico, ereto, longo em relação ao hipocótilo, ca. $55 \mathrm{~mm}$ de comprimento, castanho na base a verde na região apical, puberulento. Eofilos dois, simples, opostos, peciolados, elípticos, cartáceos, brilhosos, avermelhados a verdes, ápice acuminado, base obtusa a cuneada, margem inteira, levemente serreada no ápice, puberulentos na nervura principal da face adaxial; glabros na face abaxial. Pecíolos foliares canaliculados,
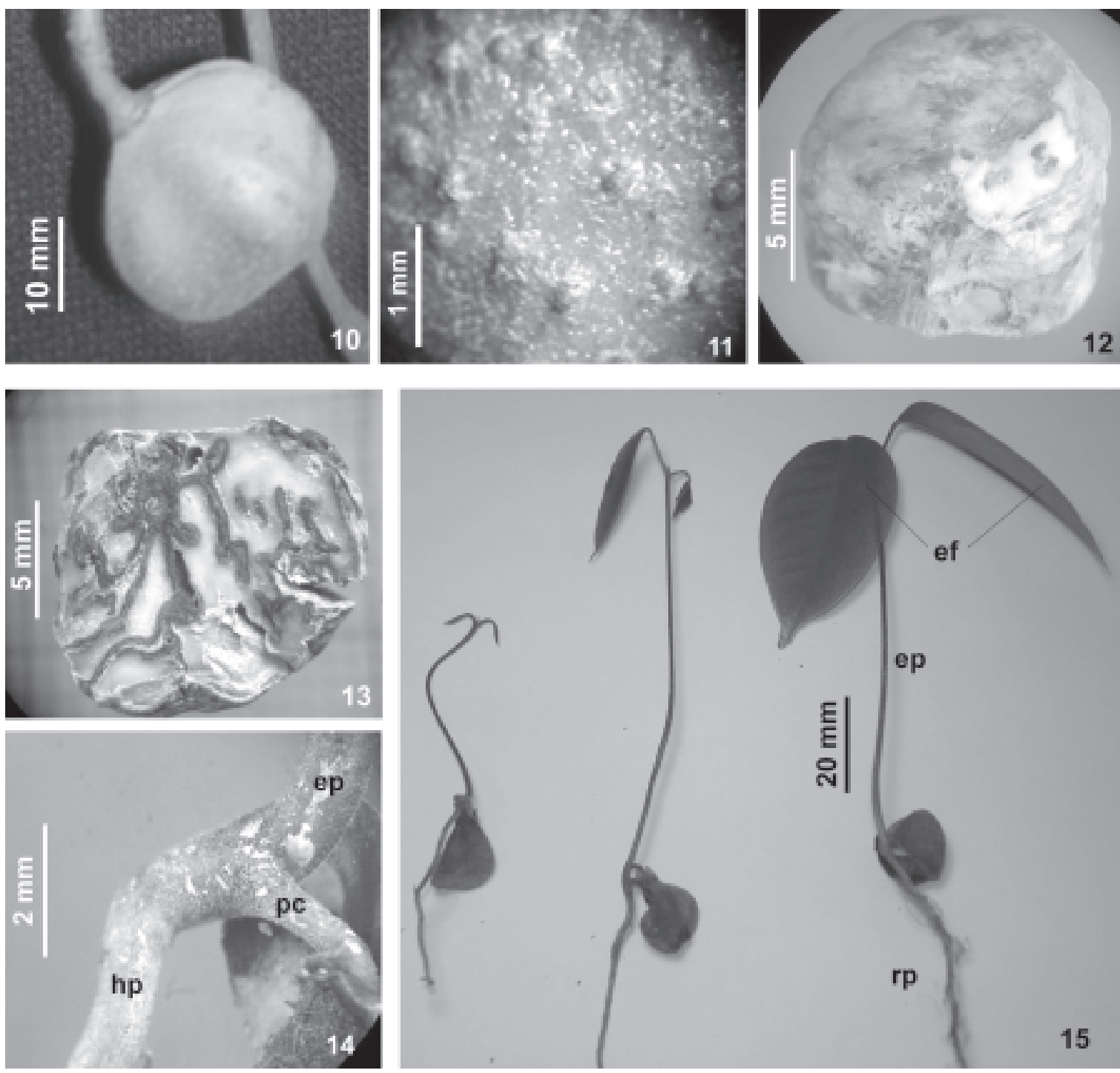

Figuras 10-15. Protium grandifolium Engl. 10. Fruto. 11. Superfície do fruto com lenticelas e tricomas. 12. Pirênio. 13. Secção longitudinal do pirênio mostrando embrião. 14. Detalhe dos pecíolos cotiledonares e hipocótilo. 15. Plântulas (rp - raiz primária, hp - hipocótilo, pi - pirênio, ep - epicótilo, ef - eofilos), F) (pc). (rp = raiz primária, rs = raízes secundárias, hp = hipocótilo, ep = epicótilo, ef = eofilos). 
ca. $15 \mathrm{~mm}$ de comprimento, puberulentos em toda sua extensão.

Protium spruceanum (Benth.) Engl.

Morfologia do fruto e pirênio - Os frutos são elipsóides, 15,5-19,5×11,5-19×10,5-13 mm, subestipitados, ligeiramente oblíquos, com ápice pouco curvado e base arredondada, com estigma freqüentemente persistente (Fig. 16). São deiscentes, abrindo-se geralmente em 2-3 valvas internamente avermelhadas e reticuladas. Exocarpo sublenhoso, liso, brilhoso, glabro, amarelo quando imaturo, vermelho quando maduro. $\mathrm{O}$ mesocarpo é relativamente delgado, carnoso, avermelhado; arilóide branco e esponjoso, envolvendo totalmente o pirênio (Fig. 17). O pirênio é ovóide a amplamente lanceolado (Fig. 18), 12-14×8-10,2× 6,6-3,8 mm, com ápice agudo a ligeiramente acuminado, base arredondada, superfície levemente ondulada e sem brilho, de consistência óssea e glabra, com espessura do endocarpo ca. de 0,69 $\mathrm{mm}$, verde em toda a sua extensão exceto na região ventral, em torno da cicatriz funicular, a qual apresenta-se diferenciada, ca. 2,41 mm do ápice, em depressão rasa, quase triangular, esbranquiçada e glabra, formando internamente uma protuberância óssea (Fig. 19); cicatriz funicular circular. Em secção longitudinal, os cotilédones são inteiros, plano-convexos, de coloração creme ou esverdeada.

Morfologia da germinação - A germinação é hipógea, criptocotiledonar. A emissão da raiz ocorre com o rompimento do ápice do pirênio e pode ser observada cerca de sete dias após a semeadura. A raiz primária apresenta-se inicialmente cilíndrica, amarelada. As raízes secundárias são inicialmente amareladas, cilíndricas, delgadas, curtas e distribuídas irregularmente ao longo da raiz primária. À medida que se desenvolve, há o aparecimento do hipocótilo. O coleto é linear, pouco evidente. O hipocótilo mostra-se semihipógeo, cilíndrico, espesso, verde-claro a esbranquiçado, curto, herbáceo, puberulento. Pecíolos cotiledonares cilíndricos, muito reduzidos e glabros. Base da lâmina cotiledonar parcialmente exposta esverdeada com manchas vináceas (Fig. 20).

Morfologia da plântula - P. spruceanum chega à fase de plântula cerca de 26 dias após a semeadura (Fig. 21). Apresenta sistema radicular axial; raiz primária cilíndrica, amarelada a castanha, glabra; raízes secundárias cilíndricas, delgadas, amareladas, distribuídas irregularmente ao longo da raiz primária. Coleto inconspícuo. O hipocótilo é muito reduzido, ca.
$2 \mathrm{~mm}$ de comprimento, amarelado e glabrescente (Fig. 20). Epicótilo cilíndrico, ereto, longo em relação ao hipocótilo, ca. $65 \mathrm{~mm}$ de comprimento, sub-lenhoso, verde-claro a amarelado, pubescente (Fig. 22). Os eofilos são dois, simples, opostos, membranáceos, ovalelípticos, verdes, opacos, ápice acuminado, base obtusa a arredondada, margem inteira, serreada no ápice, pubescentes na nervura principal da face adaxial; puberulento na face abaxial. Pecíolo foliar delgado, ca $10 \mathrm{~mm}$ de comprimento, pubescente; com duas gemas intrapeciolares e supra-axilares, pubescentes (Fig. 23).

\section{Protium gallosum Daly}

Morfologia do fruto e pirênio - Os frutos são globosos, ou obliquamente ovóides 22-23,8×16,8-19,5× 15-19,1 mm, com ápice obtuso a arredondado, base arredondada, estipitados quando imaturos (Fig. 24). São deiscentes, abrindo-se em geral em duas valvas internamente lisas, de coloração creme, 3-4 lóculos, sendo 1-3 desenvolvidos, quando unilocular, em geral, ligeiramente a fortemente curvado. Exocarpo subcoriáceo, rugoso com superfície conspicuamente verrucosa, sem brilho, de coloração laranja, tricomas eretos ou flexuosos, esparsos e hialinos (Fig. 24). Mesocarpo carnoso, delgado, de coloração creme; arilóide esponjoso, branco, envolvendo todo o pirênio. O pirênio é ovóide, dorsalmente convexo, glabro, 14,4-17,5× 8,3-9,6×7-8,8 mm, com ápice agudo, base arredondada, superfície lisa, de consistência pétrea, verde, e sem brilho, com espessura do endocarpo ca. 0,02 mm, região diferenciada, subapical, glabra, de coloração creme, cicatriz funicular elipsóide, em depressão (Fig. 25). Em secção longitudinal, o embrião é axial, reto, com eixo embrionário estreito e branco; cotilédones dominantes, plano convexos, de coloração branca (Fig. 26).

Morfologia da germinação - A germinação é epígea, fanerocotiledonar (Fig. 27). A emissão da raiz pode ser observada aos sete dias após a semeadura. A raiz primária desenvolve-se rapidamente, inicialmente curta, cônica e curva, branca. A mediada que se desenvolve, a coifa diferencia-se e afunila-se. As raízes secundárias são esparsas e curtas em relação à raiz primária, de coloração castanha (Fig. 28). Coleto indistinto como estrutura. Hipocótilo epígeo, longo em relação ao epicótilo, ca. $70 \mathrm{~mm}$ de comprimento, cilíndrico, ereto a levemente sinuoso, inicialmente verde-claro, pubescente, com tricomas hialinos. Cotilédones crassos, opostos e ascendentes, livres, isófilos, sésseis, ovóides, com ápice acuminado, endocarpo persistente aderido às lâminas cotiledonares (Fig. 29). 
Morfologia da plântula $-P$. gallosum chega à fase de plântula aos 28 dias após a semeadura. A raiz primária apresenta-se muito desenvolvida, ca. $100 \mathrm{~mm}$ de comprimento, de coloração castanho-escura. As raízes secundárias são curtas e esparsas, delgadas, ramificadas, distribuídas irregularmente em toda extensão da raiz primária. Coleto inconspícuo. Hipocótilo ereto a levemente sinuoso, cilíndrico, ca. $70 \mathrm{~mm}$ de comprimento, verde-escuro, ferrugíneo com tricomas eretos, ferrugíneos. Nós cotiledonares opostos, semicirculares, com gemas pubescente-ferrugíneas na região apical. Epicótilo cilíndrico, levemente sinuoso, ca. 15-20 mm de comprimento, verde, recoberto por tricomas tomentoso-ferrugíneos (Fig. 30). Eofilos dois, opostos, simples, peciolados, largamente elípticos, ápice acuminado (Fig. 31), margem inteira a levemente serreada no ápice, base obtusa (Fig. 32), nervura principal pubescente-ferrugínea em ambas as faces; venação broquidódroma fortemente impressa em ambas as faces. Pecíolos foliares semicilíndricos, canaliculados, recoberto por tricomas simples, eretos e ferrugíneos.

\section{Protium pilosum (Cuatrec.) Daly}

Morfologia de fruto e pirênio - Os frutos são elípticos, 11,4-19,9×5,5-13,8×4,3-12,7 mm, com ápice obtuso, base arredondada, levemente plano na face ventral, estipitado quando imaturo (Fig. 33). São deiscentes,
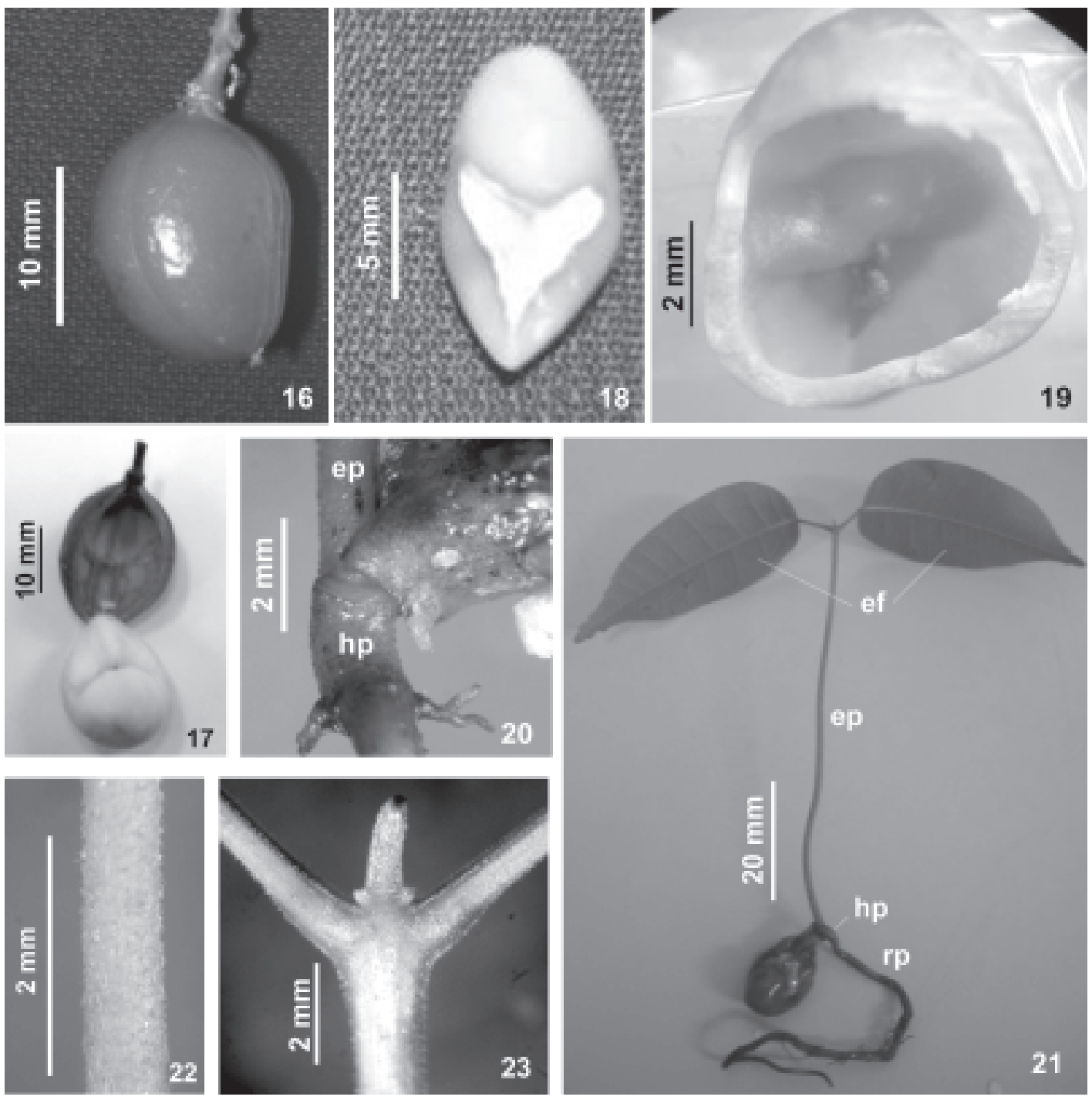

Figuras 16-23. Protium spruceanum (Benth.) Engl.. 16. Fruto maduro. 17. Fruto maduro aberto. 18. Pirênio. 19. Detalhe interno do pirênio com embrião subdesenvolvido. 20. Detalhe da plântula na região dos pecíolos cotiledonares. 21. Plântula. 22. Detalhe dos tricomas na plântula na região do epicótilo. 23. Detalhe dos tricomas na plântula nas regiões dos pecíolos e gemas. (rp $=$ raiz primária, hp = hipocótilo, ep = epicótilo, ef = eofilos). 
abrindo-se geralmente em 2-3 valvas, internamente lisas, de coloração cor de rosa, 3-4 lóculos, geralmente 1-3 desenvolvidos (Fig. 34). Exocarpo membranáceo, verde quando imaturo, alaranjado quando maduro, com superfície lisa, brilhante e glabra. Mesocarpo delgado, de coloração rósea; arilóide esponjoso, branco, cobrindo totalmente o endocarpo (pirênio). Pirênio ovóide, 14,3-17,1×8,6-11,4×6,4-8,4 mm, com ápice acuminado, base arredondada ou truncada e superfície rugosa, marrom, de consistência lenhosa, sem brilho, pubescente com tricomas esbranquiçados, espessura do endocarpo ca. $0,02 \mathrm{~mm}$, cicatriz funicular pouco evidente, elipsóide, em depressão, de coloração marrom
(Fig. 35). Em secção longitudinal o embrião é axial, com eixo hipocótilo-radícula pouco evidente, de coloração creme e cotilédones plano-convexos (Fig. 36).

Morfologia da germinação -A germinação é hipógea, criptocotiledonar (Fig. 37). O processo de germinação iniciou-se aos sete dias após a semeadura. A raiz primária surge inicialmente curta, cônica e reta com diminutos pêlos absorventes. A medida que se desenvolve, torna-se mais espessa adelgaçando-se em direção ao ápice, de coloração castanho-clara. Coleto inconspícuo. Hipocótilo hipógeo, cilíndrico, curto e
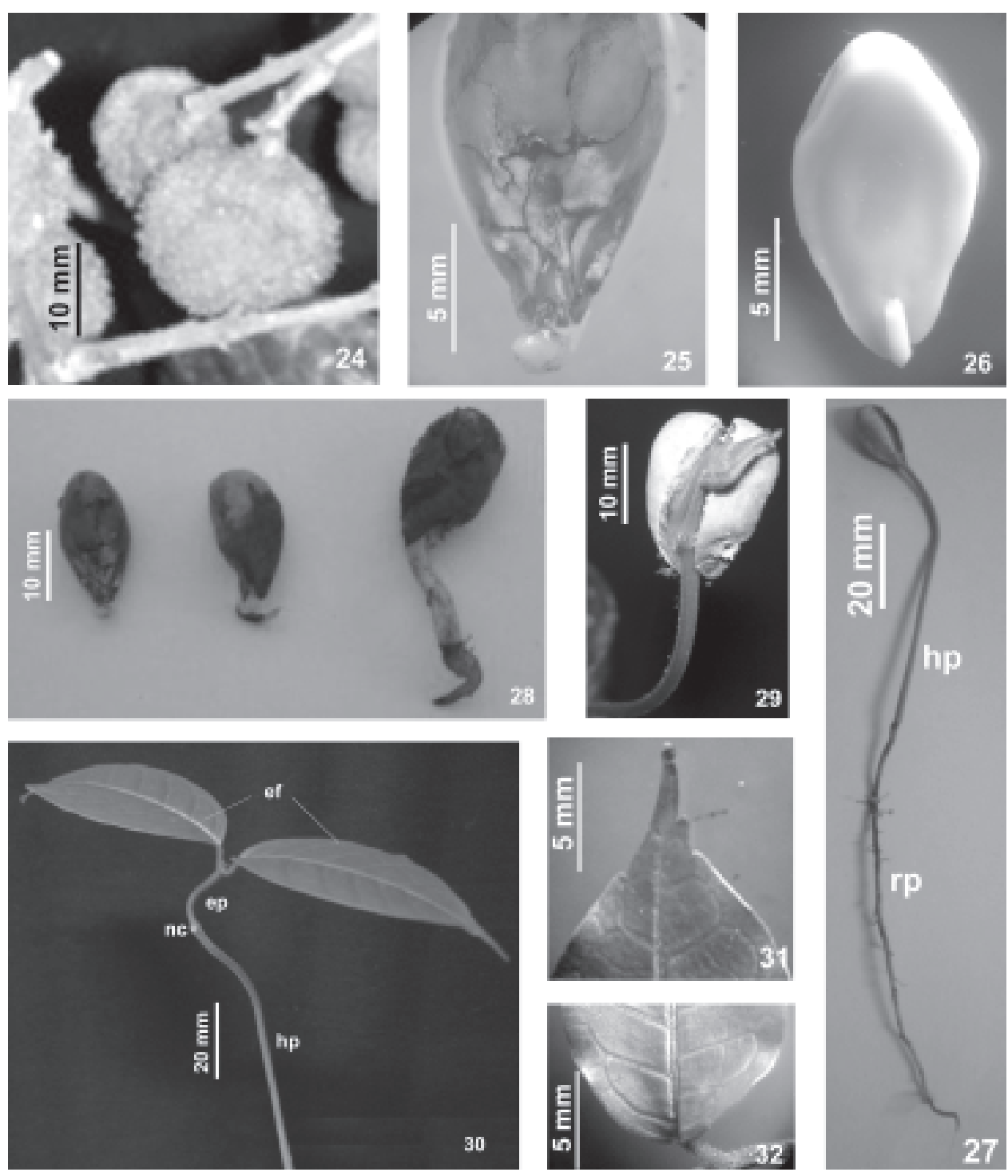

Figuras 24-32. Protium gallosum Daly. 24. Fruto maduro. 25. Pirênio. 26. Embrião. 27. Germinação epígea. 28. Detalhe da raiz primária e hipocótilo. 29. Abertura dos cotilédones e surgimento dos eofilos. 30. Plântula após a queda dos cotilédones. 31. Ápice dos eofilos. 32. Base dos eofilos. ( $\mathrm{rp}=$ raiz primária, $\mathrm{hp}=$ hipocótilo, $\mathrm{nc}=$ nó cotiledonar, ep = epicótilo, ef = eofilos). 
evidente, ca. $3 \mathrm{~mm}$ comprimento, verde escuro com manchas vináceas, densamente pubescente, tricomas retos e hialinos (Fig. 37). Epicótilo cilíndrico, da mesma coloração do hipocótilo, densamente pubescente, tricomas eretos e hialinos. Base das laminas cotiledonares parcialmente expostas, conspícuas, triangulares, e pubescentes, da mesma coloração do hipo e epicótilo.

Morfologia da plântula $-P$. pilosum chega à fase de plântula aos 32 dias após a semeadura, com o surgimento dos eofilos (Fig. 38). O sistema radicular é axial ou pivotante com raízes secundárias muito delgadas, distribuídas irregularmente ao longo do eixo da raiz principal, de coloração castanho-clara. Coleto indistinto como estrutura. Hipocótilo hipógeo, lenhoso, cilíndrico, com características semelhantes à fase da germinação. Epicótilo cilíndrico, ereto, lenhoso, castanho até a metade do seu comprimento, tornandose verde-escuro em direção ao ápice, pubescente, tricomas esparsos e hialinos. Eofilos dois, opostos, compostos, trifoliolados; folíolos oval-elípticos, subsésseis, membranáceos, ápice acuminado, margem inteira, conspicuamente serreada no ápice (Fig. 39), base obtusa a assimétrica (Fig. 40), cuneada no folíolo
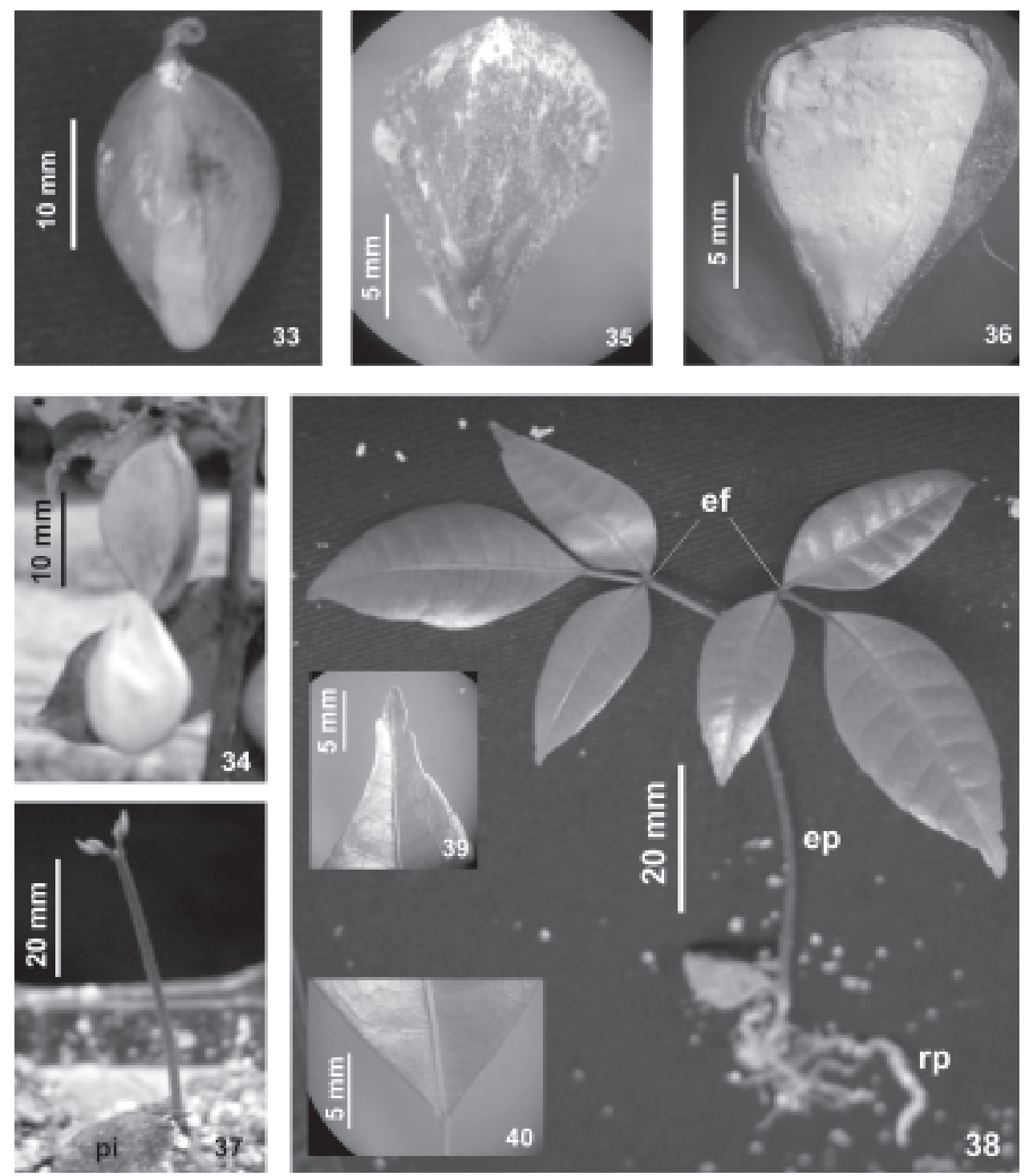

Figuras 33-40. Protium pilosum (Cuatr.) Daly. 33. Fruto maduro. 34. Fruto maduro expondo o pirênio. 35. Pirênio. 36. Secção longitudinal do pirênio mostrando embrião. 37. Germinação hipógea. 38. Plântula. 39. Ápice serreado dos eofilos. 40. Base dos eofilos. (rp = raiz primária, $\mathrm{pi}=$ pirênio, ep $=$ epicótilo, ef $=$ eofilos $)$. 
central, glabra na face adaxial, pubérula na nervura principal da face abaxial; venação broquidódroma, levemente impressa na lâmina foliar (Fig. 38). Pecíolos foliares ca. $10 \mathrm{~mm}$ de comprimento, pubescente, tricomas diminutos e hialinos; peciólulos curtos ca. $1 \mathrm{~mm}$ de comprimento. Pulvínulos proximal e distal evidentes e pubescentes.

\section{Protium opacum Swart}

Morfologia do fruto e pirênio - os frutos são globosos, 21,8-29,3×22,6-35,7×19,6-29,1 mm, pêndulos e vistosos, sésseis, 4-5 lóculos, sendo a maioria com 1-2 desenvolvidos (Fig. 41). São deiscentes em duas a três valvas, internamente brancas. Exocarpo lenhoso, lenticelado, verde-amarelado, com superfície áspera e glabra. Mesocarpo carnoso, delgado, cremeesverdeado; arilóide carnoso, branco envolvendo totalmente o pirênio (Fig. 42). O pirênio é ovado a suborbicular, 12,6-17,7×15,7-22,5×11,2-27,4 mm, com superfície irregular de consistência sublenhosa, brilhante, verde e glabro, região diferenciada, esbranquiçada e glabra, ca. $5 \mathrm{~mm}$ do ápice; cicatriz funicular punctiforme (Fig. 43). Em secção longitudinal, os cotilédones são contortuplicados (Fig. 44).

Morfologia da germinação - A germinação é semihipógea, criptocotiledonar (Fig. 45). A emissão da raiz primária ocorre com o fendimento do ápice do pirênio, aos oito dias após a semeadura. A raiz primária apresenta-se inicialmente cônica, creme e glabra. Com o desenvolvimento, torna-se creme e de maior diâmetro com raízes secundárias esparsas ao longo da raiz principal. Simultaneamente ao desenvolvimento da raiz, observa-se o surgimento do hipocótilo, já que o coleto é inconspícuo como estrutura. O hipocótilo é curto, ca. $4 \mathrm{~mm}$ de comprimento, hipógeo, avermelhado, cilíndrico e pubescente (Fig. 46). Pecíolos cotiledonares pouco evidentes da mesma coloração do hipocótilo, base das lâminas cotiledonares discretamente expostas.

Morfologia da plântula $-P$. opacum chega à fase de plântula ca. 27 dias após a semeadura (Fig. 47). Sistema radicular axial; raiz primária cilíndrica, afunilando-se em direção ao ápice, de coloração castanho-clara; raízes secundárias ramificadas, delgadas, distribuídas em toda extensão da raiz primária, de coloração castanha. Coleto indistinto como estrutura. Hipocótilo curto, avermelhado, com as mesmas características e desenvolvimento da fase da germinação. Epicótilo cilíndrico, ereto, ca. $60 \mathrm{~mm}$ de comprimento, inicialmente avermelhado à posteriormente castanho na base e verde em direção ao ápice, conspicuamente pubescente, tricomas simples, eretos e hialinos (Fig. 48). Eofilos dois, opostos, simples, peciolados, amplamente elípticos, cartáceos, verdes, brilhantes, ápice longo acuminado (Fig. 49), levemente retuso em pelo menos um dos eofilos, base obtusa (Fig. 50), margem inteira, glabros em ambas as faces; venação broquidódroma, com nervuras fortemente impressas nas lâminas foliares (Fig. 47), com nervuras primárias, secundárias e terciárias evidentes na face abaxial. Pecíolo foliar com 4,2-5,8 mm de comprimento, canaliculado e pubescente (Fig. 51). Segundo eofilo 1, com características semelhantes aos primeiros (Fig. 52).

\section{Protium crassipetalum Cuatrec.}

Morfologia do fruto e pirênio - Os frutos são globosos ou ovóides, 23-28×15,2-19,2 ×15,1-18,3 mm, subestipitados quando imaturos, sésseis quando maduros, ápice obtuso e proeminente, base arredondada (Fig. 53). São discentes, abrindo-se em 2-3 valvas internamente não reticuladas, de coloração avermelhada e sem brilho, 3-4 lóculos, sendo 1-3 desenvolvidos. Exocarpo membranáceo, verde quando imaturo, vermelho a vináceo quando maduro, brilhoso e glabro. Mesocarpo delgado, carnoso e avermelhado; arilóide esponjoso, espesso, de coloração branca (Fig. 54). O pirênio é oblongo, com região ventral-central proeminente em toda sua extensão, 15-18,9 ×7,59,7×6,2-7,9 mm, ápice acuminado ou agudo, base arredondada, de consistência subóssea, com superfície lisa, opaca, glabra e marrom, cicatriz funicular pouco diferenciada, ca. $2 \mathrm{~mm}$ do ápice (Fig. 55). Em secção longitudinal, os cotilédones são contortuplicados (Fig. 56).

Morfologia da germinação - Germinação hipógea, criptocotiledonar (Fig. 57). A emissão da raiz primária ocorre aos 9 dias após a semeadura com o rompimento do ápice do pirênio, às vezes lateralmente ao ápice. Inicialmente a raiz primária é delgada, levemente sinuosa, creme e glabra. As raízes secundárias são muito curtas durante a fase de germinação. Coleto inconspícuo. Hipocótilo herbáceo, hipógeo, castanho e glabro. Epicótilo epígeo, cilíndrico e pubescente. Pecíolos cotiledonares inconspícuos. Lâminas cotiledonares parcialmente expostas, de coloração verde.

Morfologia da plântula $-P$. crassipetalum chega à fase de plântula 43 dias após a semeadura (Fig. 58). O sistema radicular é axial, pouco alongado, ca. 40,5 mm de comprimento. As raízes secundárias são delicadas, curtas, castanhas, concentrando-se na região mais 
próxima ao ápice. Coleto inconspícuo. Hipocótilo curto, ca. $2 \mathrm{~mm}$ de comprimento. Epicótilo cilíndrico, ereto, muito longo em relação ao hipocótilo. ca. 122,5 mm compr., pubescente, tricomas diminutos e hialinos. À medida que se desenvolve, torna-se de coloração castanha com tricomas diminuto-tomentosos e ferrugíneos. Eofilos dois, simples, opostos, levemente pêndulos, cartáceos, oval-elípticos a oblongo-elípticos, ápice caudado (Fig. 59), acúmen com 15-20 mm compr., base arredondada (Fig. 60), margem inteira, glabros em ambas as faces; venação broquidódroma, levemente impressa na lâmina foliar. Pecíolos foliares 9-15 mm compr., levemente canaliculado e puberulento.

\section{Protium apiculatum Swart}

Morfologia do fruto e pirênio - Os frutos são globosos ou ovóides, 19-22,6×16,4-35,4×14,5-28,3mm, com ápice agudo a ligeiramente acuminado e encurvado, pedicelados (Fig. 61). São deiscentes, abrindo-se, em geral, em 4-5 valvas, internamente não reticuladas, vermelhas a rosadas, 3-4 lóculos, sendo em geral, 1-3 desenvolvidos. Exocarpo sublenhoso, de coloração laranja, sem brilho, glabro. O mesocarpo é carnoso, delgado, de coloração creme; arilóide vermelho quando maduro, esverdeado com manchas avermelhadas quando imaturo, envolvendo completamente o pirênio (Fig. 62). O pirênio é ovado a oblongo-oval, com ápice
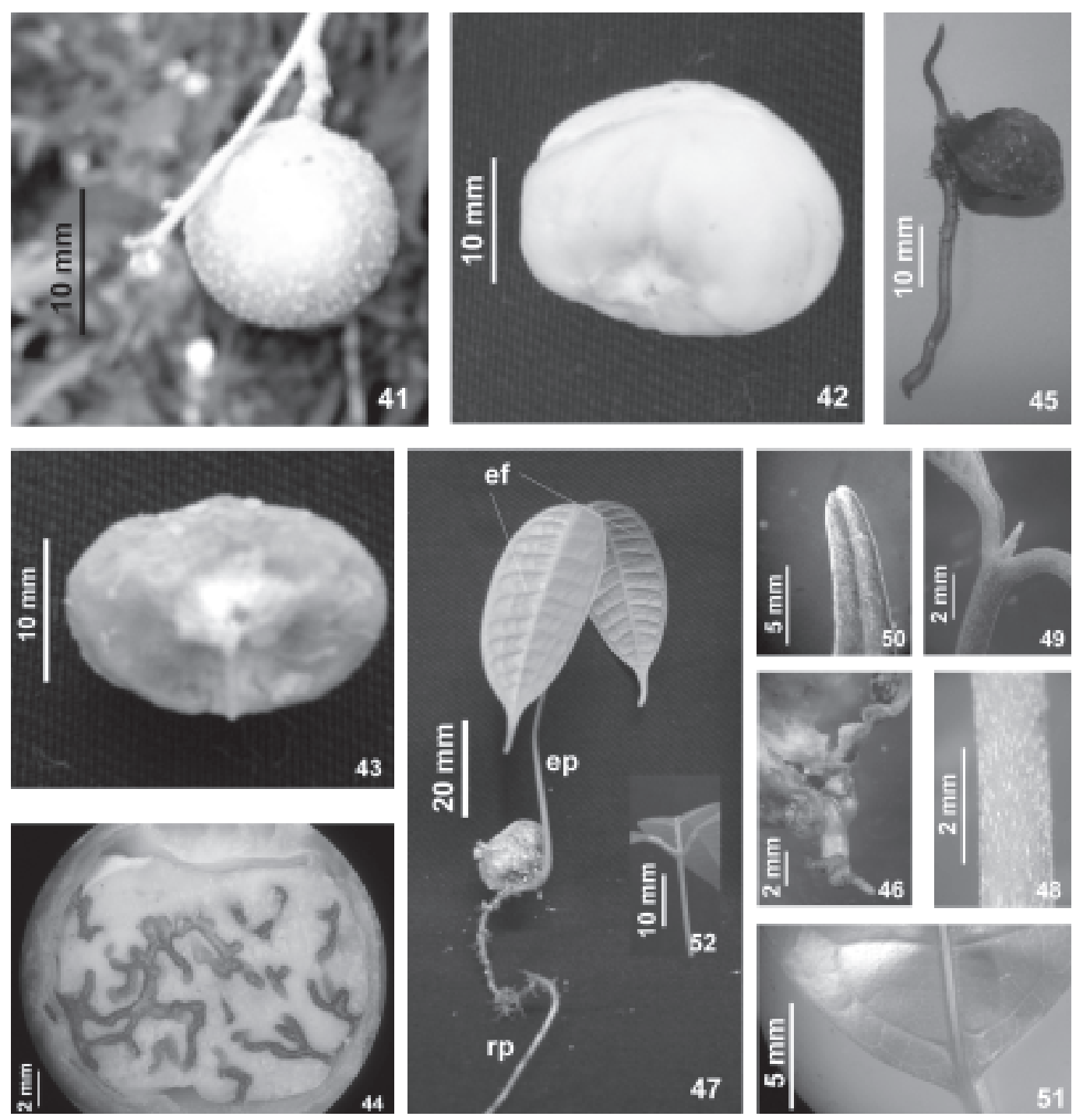

Figuras 41-52. Protium opacum Swart. 41. Fruto maduro. 42. Pirênio envolvido pelo arilóide. 43. Pirênio. 44. Embrião. 45. Germinação semi-hipógea. 46. Detalhe do hipocótilo durante a germinação. 47. Plântula. 48. Detalhe dos tricomas no epicótilo. 49. Detalhe dos pecíolos dos eofilos. 50. Ápice do eófilo. 51. Base do eófilo. 52. Detalhe do segundo eófilo. ( $\mathrm{rp}=$ raiz primária, ep $=$ epicótilo, ef $=$ eofilos) 
acuminado, base arredondada a truncada, superfície levemente irregular, de consistência lenhosa, glabra e sem brilho (Fig. 63), com espessura do endocarpo 0,40 $\mathrm{mm}$, de coloração verde-escura, exceto na face ventral, no ápice, que apresenta uma região diferenciada apical, de coloração creme a esbranquiçada, cicatriz funicular em depressão, oblonga. Em secção longitudinal, os cotilédones são plano-convexos, de coloração branca (Fig. 64).

Morfologia da germinação - A germinação é epígea, fanerocotiledonar (Fig. 65). A emissão da raiz primária ocorre com o rompimento no ápice do pirênio e pode ser observada aos 4 dias após a semeadura. A raiz primária apresenta-se cilíndrica, afunilando-se em direção ao ápice, inicialmente creme e glabra. À medida que se desenvolve, a raiz primária torna-se de coloração castanha. As raízes secundárias são curtas e pouco evidentes esparsamente distribuídas irregularmente ao longo da raiz primária. Coleto inconspícuo como estrutura. Hipocótilo cilíndrico, verde e pubescente (Fig. 66). Cotilédones crassos, verde-escuros, opostos, ascendentes, parcialmente abertos; endocarpo persistente e aderido ao cotilédone (Fig. 67).

Morfologia da plântula $-P$. apiculatum chega à fase de plântula cerca de 29 dias após a semeadura (Fig. 68). Apresenta sistema radicular axial; raiz primária cilíndrica, castanha e glabra; raízes secundárias cilíndricas, muito delgadas, de coloração castanhas, não ramificadas, esparsas, distribuídas irregularmente ao longo da raiz primária. Coleto não evidente. Hipocótilo
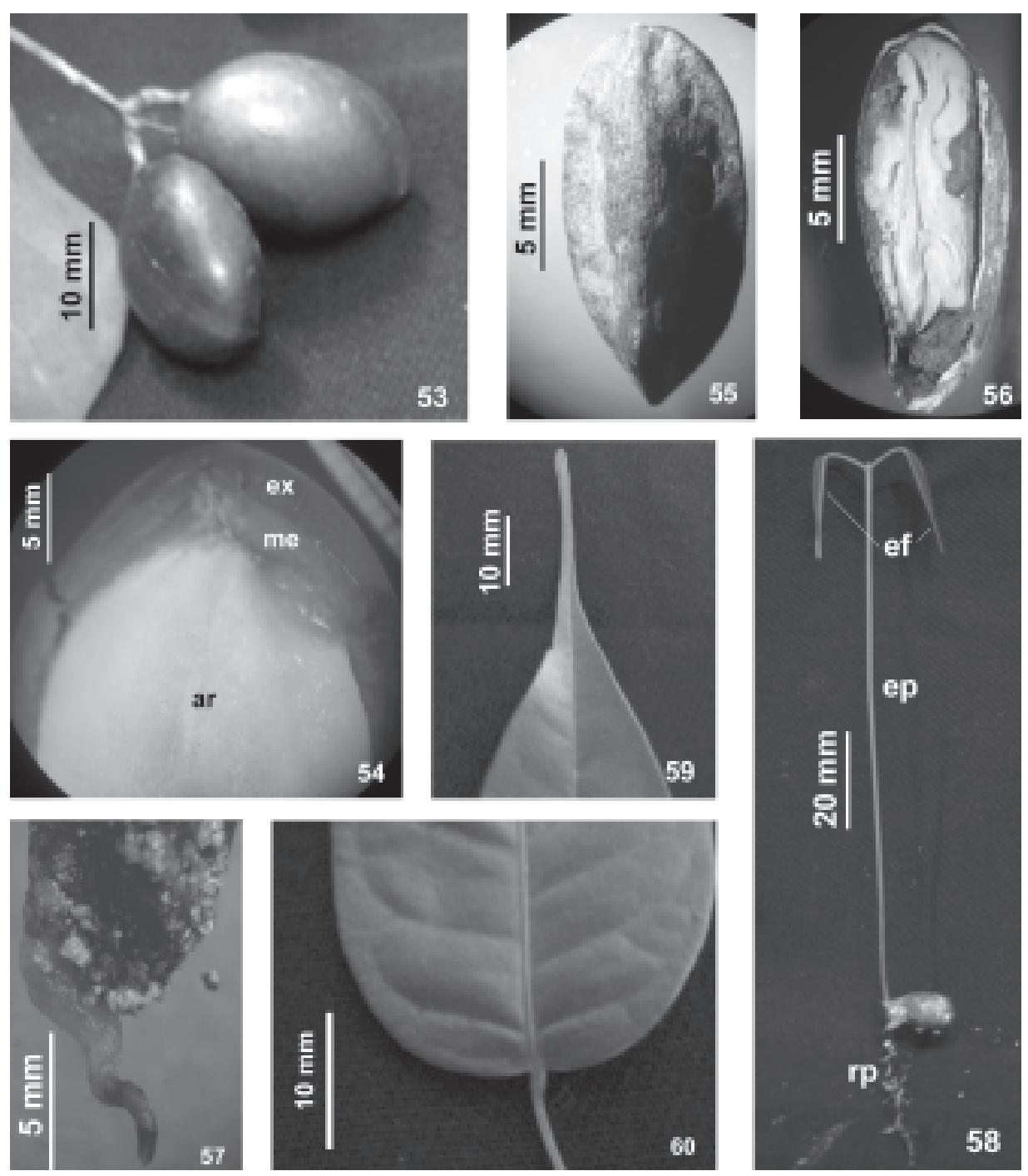

Figuras 53-60. Protium crassipetalum Cuatrec.. 53. Fruto maduro. 54. Detalhe do exocarpo, mesocarpo e arilóide. 55. Pirênio. 56. Embrião. 57. Germinação hipógea. 58. Plântula. 59. Ápice do eófilo. 60. Base do eófilo. (ex = exocarpo, me $=$ mesocarpo, $\operatorname{ar}=\operatorname{arilóide,~} \mathrm{rp}=$ raiz primária, ep = epicótilo, ef = eofilos). 
cilíndrico, 60-80 mm compr., pubescentes, tricomas simples, hialinos a ferrugíneos. Cotilédones não persistentes nessa fase de desenvolvimento. Nó cotiledonar elíptico, com gema apical pubescente, com tricomas diminutos e hialinos (Fig. 69). Epicótilo semicilíndrico, levemente sinuoso, canaliculado, ca. 15-20 mm compr., castanho-esverdeado, pubescente. Eofilos dois, opostos, simples, oval-elípticos, membranáceos, verdes, ápice acuminado (Fig. 70), base arredondada (Fig. 71), margem inteira até a metade do seu comprimento, serreada em direção ao ápice; venação broquidódroma, fortemente impressa na lâmina foliar, nervura principal pubérula em ambas as faces. Pecíolos foliares curtos, 1-3 mm compr., canaliculados, pubescentes (Fig. 71).

\section{Protium hebetatum Daly}

Morfologia do fruto e pirênio - Os frutos são globosos a ovados, 19-28,7×21-26,7×19-25,7 mm, com ápice obtuso a arredondado, curto estipitado (Fig. 72). São deiscentes, abrindo-se geralmente por 3-4 valvas, internamente brancas, pouco reticuladas, 3-4 lóculos, sendo 1-3 desenvolvidos. Exocarpo sublenhoso, liso, brilhante, verde e glabro. O mesocarpo é delgado, verde-claro; arilóide carnoso, esbranquiçado hialino, envolvendo totalmente o pirênio (Fig. 73). O pirênio é amplamente obovado, 12,9-21,2×11,9-17,7× 9,1-15,7 mm, com ápice acuminado, base truncada, superfície lisa, sublenhosa, pubescente, com espessura do endocarpo fina e quebradiça, ca. $0,24 \mathrm{~mm}$, de coloração vinácea a quase enegrecida, região
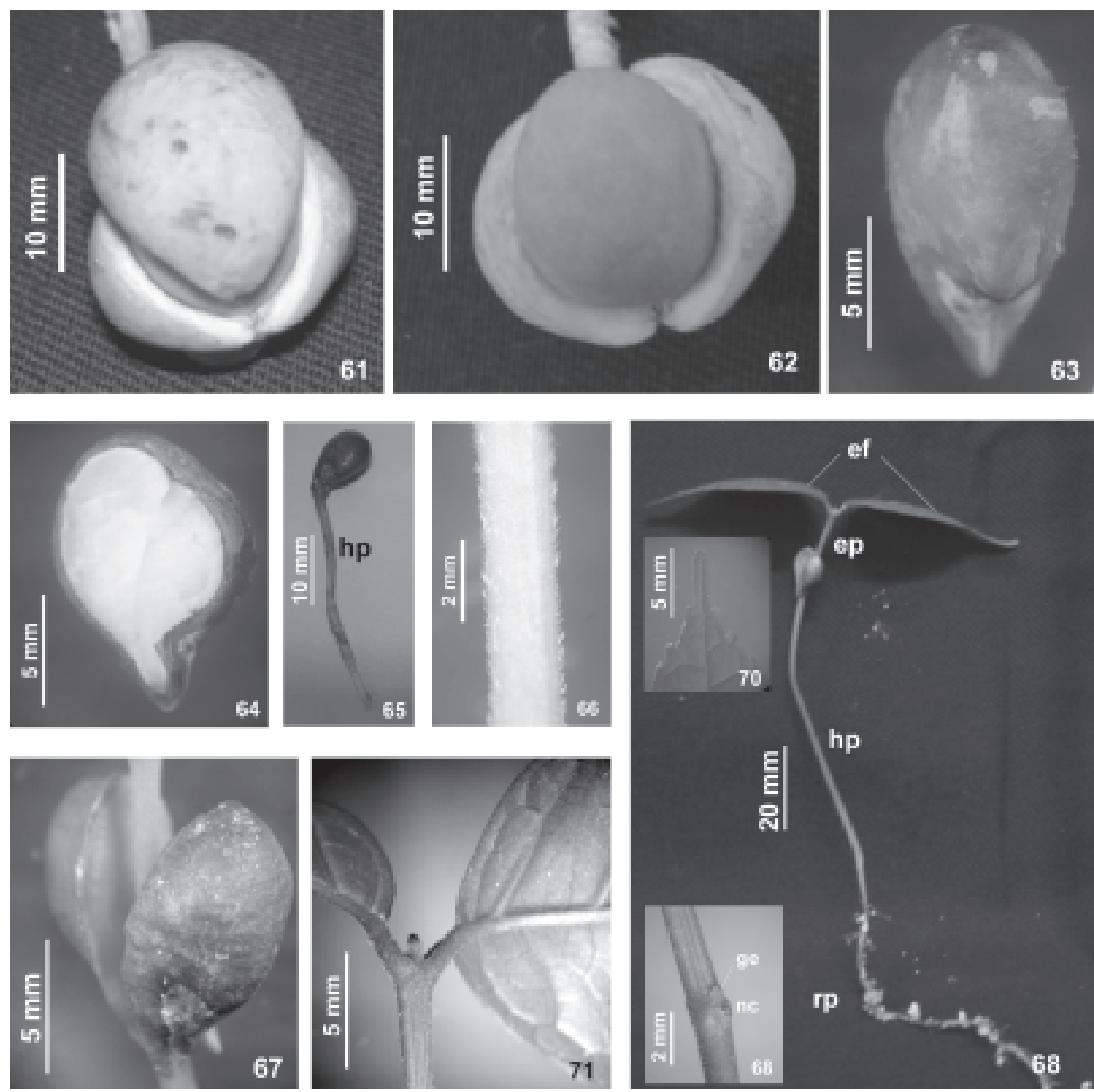

Figuras 61-71. Protium apiculatum Swart. 61. Fruto maduro em fase de deiscência. 62. Fruto maduro aberto expondo arilóide. 63. Pirênio. 64. Embrião. 65. Germinação epígea. 66. Detalhe dos tricomas no hipocótilo. 67. Detalhe dos cotilédones durante a germinação. 68. Plântula. 69. Detalhe do nó cotiledonar e gema apical. 70. Ápice do eófilo. 71. Detalhe da base e pecíolos foliares. (rp = raiz primária, $\mathrm{hp}=$ hipocótilo, $\mathrm{nc}=$ nó cotiledonar, $\mathrm{ge}=$ gema, ep = epicótilo, ef = eofilos $)$. 
diferenciada, proeminente, distante do ápice ca. 2,5 $\mathrm{mm}$, cor de vinho e glabrescente, cicatriz funicular em depressão, elíptica (Fig. 74). Em secção longitudinal, os cotilédones são contortuplicados (Fig. 75).

Morfologia da germinação - A germinação é do tipo hipógea, criptocotiledonar (Fig. 76). A emissão da raiz ocorre com o rompimento no ápice do pirênio e pode ser observada cerca de sete dias após a semeadura. A raiz primária apresenta-se cilíndrica, afunilando-se em direção ao ápice, inicialmente creme e glabra. À medida que se desenvolve, a raiz primária torna-se amarelada a castanha. As raízes secundárias são inicialmente amareladas, com pêlos absorventes, cilíndricas, delgadas e distribuídas na base da raiz primária. Coleto inconspícuo. Hipocótilo curto, ca. $3 \mathrm{~mm}$ compr. (Fig.
77). Pecíolos cotiledonares expostos, cilíndricos, ca. 3,5 mm compr., de coloração castanha, pubescentes. Base das lâminas cotiledonares parcialmente expostas, oblongas, de coloração esverdeada.

Morfologia da plântula $-P$. hebetatum chega à fase de plântula cerca de 43 dias após a semeadura (Fig. 78). Apresenta sistema radicular axial; raiz primária cilíndrica, marrom, glabra; raízes secundárias cilíndricas, delgadas, não ramificadas, marrons a castanhas, distribuídas irregularmente ao longo da raiz primária. Coleto inconspícuo. Hipocótilo distinto, ca. $4 \mathrm{~mm}$ compr. (Fig. 79). Epicótilo cilíndrico, ereto, longo, 5-12(17) cm compr., marrom-esverdeado, pubescenteferrugíneos. Eofilos geralmente dois, trifoliolados e opostos, ou inicialmente um, e unilateral, oval-elípticos
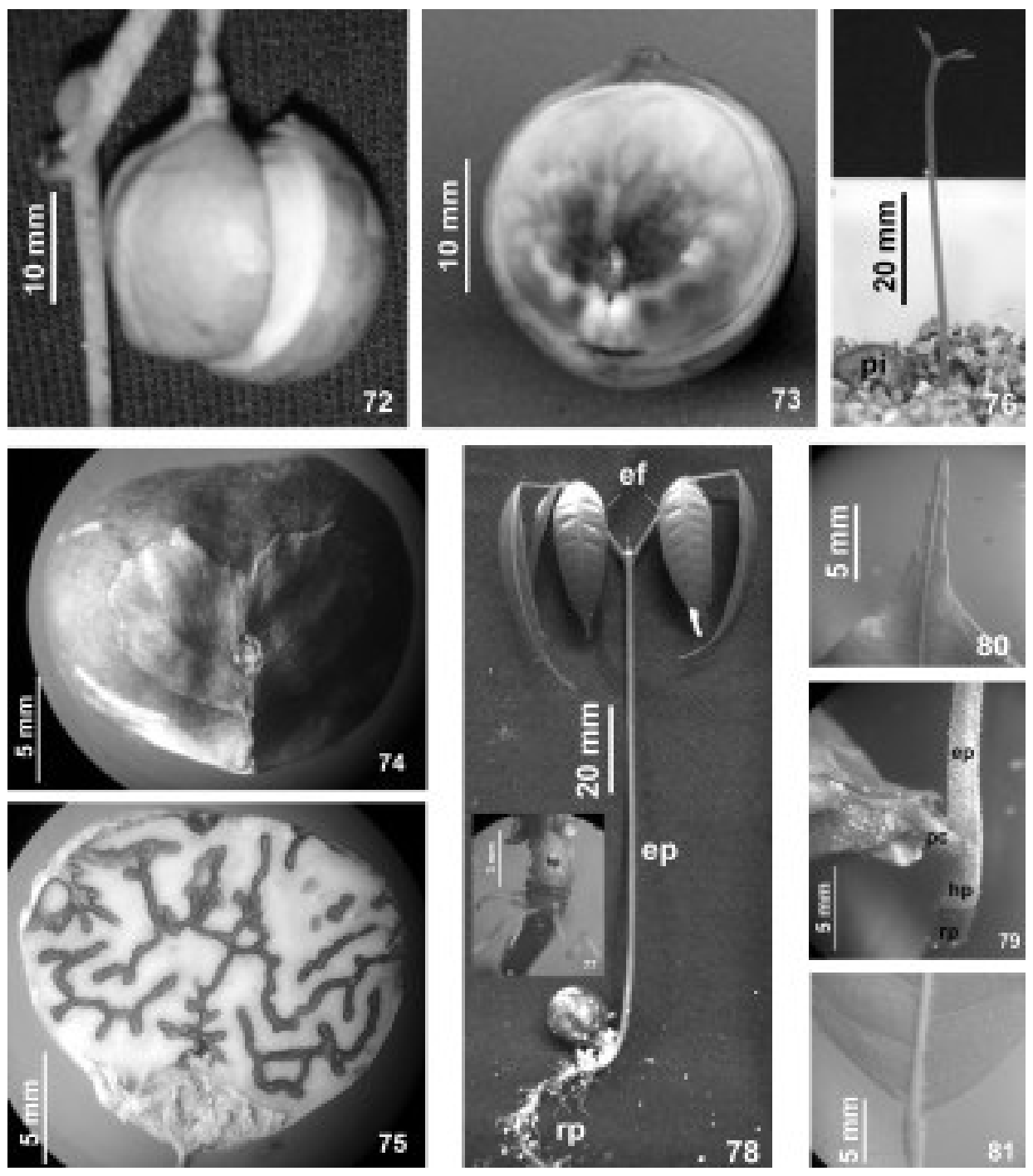

Figuras 72-81. Protium hebetatum Daly. 72. Fruto maduro em deiscência. 73. Fruto aberto evidenciando o arilóide. 74. Pirênio, com detalhe da cicatriz funicular. 75. Embrião. 76. Germinação hipógea. 77. Detalhe do hipocótilo. 78. Plântula. 79. Detalhe do hipocótilo. 80. Ápice do eófilo. 81. Base do eófilo. (rp = raiz primária, hp = hipocótilo, pc = pecíolo cotiledonar, ep = epicótilo, ef = eofilos). 
a elípticos, inicialmente vermelhos a posteriormente verdes, membranáceos, ápice longo acuminado (Fig. 80), acúmen ca. 1-1,5(2) cm compr., base arredonda a obtusa (Fig. 81), raramente assimétrica, margem inteira, levemente serreada no ápice; nervura principal glabra na face adaxial, pubérula na face abaxial. Pecíolos foliares semicilíndricos, 1,3-2(3) cm compr., densamente pubescentes, tricomas simples e hialinos, peciólulos dos folíolos laterais curtos, $0,2-0,5 \mathrm{~cm}$ compr., peciólulos dos folíolos centrais com 0,5-1,5(1,9) cm, recobertos por tricomas semelhantes aos pecíolos foliares.

\section{Discussão}

Morfologia dos frutos de Protium - É comum referir mais de um tipo de fruto para Protium Burm. f., isto porque o gênero apresenta o fruto semelhante a uma drupa, porém é deiscente.

Dentre as várias opiniões sobre os frutos carnosos e deiscentes de Protium, Roosmalen (1985) ao descrever frutos de 14 espécies de Protium para flora da Guiana, classifica-os como drupas. Já Spjut (1994) refere-os como nuculânios, por se tratar de frutos simples, com pericarpo seco, de uma ou mais sementes, indeiscente ou ocasionalmente deiscente. Enquanto Barroso et al. (1999) classificam como filotrimídio, correspondendo ao fruto cujo exocarpo se abre em valvas, ficando as sementes encerradas no endocarpo lignificado, cobertas parcial ou totalmente por mesocarpo mais ou menos carnoso ou lenhoso.

Apesar das diferentes interpretações atribuídas aos frutos desse gênero, o presente estudo considera os frutos de Protium drupáceos pelas características semelhantes a drupas, apesar de serem deiscentes, com 4-5 lóculos (normalmente com 1-3 desenvolvidos), globosos, ovóides, elípsóides ou oblongos, freqüentemente oblíquos; em geral, vermelhos quando maduros, menos freqüentemente verdes ou vináceos; superfície lisa ou lenticelada ou rugosa, brilhante ou opaca; geralmente glabros, menos freqüentemente pilosos; as valvas podem ser internamente brancas, rosadas ou avermelhadas.

Diferentes opiniões também ocorrem na definição de um termo adequado para a polpa adocicada que envolve o pirênio. Daly (1987) afirma que arilos verdadeiros são associados às sementes, enquanto que a estrutura análoga em Protium está associada ao pirênio, sendo, por isso, chamada de "pseudarilo" em seu trabalho. Concordando em parte com isto, Barroso et al. (1999), prefere considerar essa estrutura como mesocarpo carnoso ou lenhoso. Beltrati (1992) define arilóide ou falso arilo como uma excrescência que se origina no topo do tegumento externo, em torno do poro micropilar, que recobre total ou parcialmente o óvulo. A autora relata que alguns autores preferem considerar o arilo como qualquer excrescência que se forma na superfície do óvulo, que se localiza em diferentes pontos do tegumento externo. Considerando as diferentes opiniões sobre a estrutura carnosa que envolve o pirênio das espécies estudadas, o termo arilóide é aqui utilizado pela estrutura envolver a superfície do pirênio e não diretamente a semente. Para uma melhor definição em Protium são então necessários estudos ontogenéticos para confirmar qual a camada corresponde ao exo, meso e endocarpo.

A maioria das espécies estudadas apresentou arilóide de coloração branca, variando de consistência carnosa a esponjosa. Apenas $P$. apiculatum apresentou arilóide vermelho em frutos maduros ou brancos com manchas rosadas em frutos quase maduros. Até o momento, em observações de campo, foi também verificada a presença de arilóide vermelho em $P$. aracouchini (Aubl.) March..

$\mathrm{O}$ endocarpo duro envolvendo a semente recebe o nome de pirênio. O pirênio é uma estrutura significativa tanto para auxiliar na identificação de frutos, como também de plântulas, uma vez que, em geral, é persistente nessa fase do ciclo de vida. Dentre os caracteres utilizados para auxiliar na taxonomia destacam-se: forma, coloração, presença ou ausência de tricomas, textura, consistência e espessura. Os pirênios em Burseraceae são geralmente ovóides, com ápice agudo, de consistência cartilaginosa ( $P$. paniculatum variedade riedelianum) a óssea ( $P$. subserratum), glabras ou pubescentes, com superfície diferenciada em torno da cicatriz funicular, de diferentes formas e tamanhos. As sementes são exalbulminosas, com embrião crasso, cotilédones inteiros e plano-convexos ou contortuplicados e eixo hipocótilo-radícula curto (Daly 1987; Cuatrecasas 1957; Barroso et al. 1999).

Limites na germinação das Burseraceae - As espécies estudadas no presente trabalho apresentaram comportamentos diferentes. Em P. spruceanum, das unidades semeadas apenas $10 \%$ germinaram e chegaram à fase de plântula. Isso se deve, provavelmente, ao endocarpo duro que, segundo Ferraz et al. (2004), retarda a germinação por vários meses; e a imaturidade do embrião, observada em 
algumas sementes cujos pirênios foram seccionados. Daly (1987) explica que, após a fertilização, o fruto e o pirênio desenvolvem-se mais rápido que a semente, alcançando seu tamanho máximo bem antes do embrião expandir-se e ocupar a cavidade interna do pirênio. Sendo assim, acredita-se que os frutos foram coletados e os pirênios semeados durante essa fase. Condições semelhantes foram observadas por Abreu et al. (2005) em sementes de cataia (Drimys brasiliensis Miers. - Winteraceae) que apresentam dormência por imaturidade embrionária. Segundo o autor, não há sincronia no desenvolvimento morfológico entre o fruto e o embrião, ou seja, quando os frutos estão maduros, os embriões ainda se encontram na fase rudimentar no momento da dispersão.

Outras espécies de Protium, com frutos completamente maduros, também apresentaram problemas de germinação. Em P. aracouchini (Aubl.) Marchand apenas 10\% das 100 unidades semeadas germinaram enquanto em $P$. pilosissimum Engl. não houve germinação. Atualmente, não se pode afirmar quais os fatores que influenciaram no processo germinativo, mas existe a possibilidade de ser devido à imaturidade do embrião ou a predação dos pirênios por insetos e/ou pássaros. Muitos pirênios de $P$. spruceanum e $P$. crassipetalum apresentaram-se perfurados, após o beneficiamento. Nesse contexto, observa-se que para algumas espécies de Protium, a maturidade dos frutos nem sempre é uma condição necessária para indicar que os embriões estão aptos para germinar, mas a integridade e o completo desenvolvimento do embrião são fundamentais para a germinação.

Germinação e morfologia das plântulas das Burseraceae - Os padrões de germinação e a morfologia da plântula das Burseraceae oferecem um conjunto de caracteres suficientemente diverso para merecer mais atenção e uso na sistemática da família. A germinação é criptocotiledonar ou fanerocotiledonar, com cotilédones variando de palmatífidos e contorduplicados (a maioria de Dacryodes) a simples e planoconvexos (Tetragastris e parte de Protium) ou trifoliolados (parte de Bursera) (Duke 1969; Daly, obs. pess.). Para Guillaumin, apud Vogel (1983) os (para) cotilédones epígeos, lobados ou palmados, ocorrem nos gêneros Boswellia, Bursera, Canarium, Dacryodes, Garuga, Protium e Santiria enquanto que nos gêneros Aucoumea, Crepidospermum, Scutinanthe e Tetragastris são epígeos e inteiros. Por outro lado, em Haplolobus os (para) cotilédones são hipógeos e planoconvexos (Leenhouts apud Vogel 1983).
O gênero Protium mostra quase tanta diversidade como a família inteira: os cotilédones podem ser inteiros ou lobados e retos, contorduplicados ou dobrados no sentido vertical e/ou horizontal; a germinação pode ser hipógea ou epígea e cripto ou fanerocotiledonar; e tanto os eofilos como os metafilos podem ser opostos ou alternos e simples, unifoliolados, trifoliolados ou pinados, com margem inteira ou serrilhada (Duke 1969; Vogel 1983; Daly, obs. pess.).

Dentre as nove espécies analisadas neste trabalho, a grande maioria dos taxa apresentou germinação (semi) hipógea-criptocotiledonar - $P$. spruceanum, $P$. grandifolium, $P$. polybotryum ssp. blackii, $P$. pilosum, $P$. opacum, $P$. crassipetalum e $P$. hebetatum. Enquanto apenas $P$. gallosum e $P$. apiculatum são fanerocotiledonares, com cotilédones epígeo-carnosos.

O hipocótilo reduzido ou nulo nestas espécies, caracterizou a germinação do tipo hipógea por manter os pirênios ao nível do solo. No desenvolvimento pósseminal, o hipocótilo pode ser epígeo, hipógeo ou semihipógeo, sendo que nas espécies hipógeas o desenvolvimento do hipocótilo é pequeno, muito reduzido ou mesmo nulo, tanto na plântula como no embrião (Oliveira 1993).

Neste trabalho observa-se que houve pouca variedade com relação à morfologia de plântulas. Contudo, após o estudo, foi possível reconhecer as peculiaridades de cada taxon. Estas características além de muito importantes, servem como subsídio para o reconhecimento das espécies em campo.

A maioria das espécies apresentou eofilos simples e opostos, raramente unilateral. Eofilos compostos e germinação criptocotiledonar foram observados em $P$. hebetatum e P. pilosum, mas apesar disso, ambas as espécies são facilmente distintas, tanto na morfologia da lâmina foliar quanto na coloração. P. hebetatum tem eofilos inicialmente vermelhos a posteriormente verdes, enquanto $P$. pilosum são verdes, distintamente serreado no ápice. Além disso, os pecíolos foliares são mais longos em $P$. hebetatum (ca. $22 \mathrm{~mm}$ ), enquanto P. pilosum tem ca. $7 \mathrm{~mm}$ de comprimento.

Dentre as nove espécies estudadas, ressalta-se que $P$. crassipetalum e $P$. polybotryum estão estreitamente relacionadas, apresentando ambas as espécies eofilos oval-elípticos com ápice caudado, entretanto diferenciamse entre si pelo epicótilo mais longo em $P$. crassipetalum (ca. $122,5 \mathrm{~mm}$ ) e em $P$. polybotryum com $50-90 \mathrm{~mm}$. Outro fator que pode ser mencionado refere-se à morfologia do pirênio, oblongos em ambas as espécies, contudo $P$. crassipetalum é evidentemente proeminente na região ventral, demarcada por região estreita e 
angulosa ao longo de seu comprimento. Para ambas as espécies, os frutos são facilmente diferenciáveis: oval com ápice arredondado em $P$. polybotryum e obtuso e proeminente em $P$. crassipetalum.

Embora, aparentemente, a morfologia geral das plântulas de $P$. spruceanum e $P$. grandifolium sejam muito próximas, $P$. spruceanum apresenta eofilos ovalelípticos, membranáceos com gemas intrapeciolares conspícuas e venação broquidódroma pouco evidente, enquanto $P$. grandifolium apresenta eofilo elíptico, com venação marcadamente broquidódroma em ambas as faces. A presença de gemas em $P$. spruceanum foi confirmada na espécie adulta, as quais são protegidas por escamas e recobertas por tricomas simples, dispostas acima e próximas da axila das folhas, ao longo dos ramos, evidenciando que o estudo de plântulas pode contribuir com eficiência na identificação das espécies.

Ainda com relação à morfologia de plântulas das espécies estudadas, ressalta-se a venação broquidódroma fortemente impressa na lâmina foliar de P. opacum, P. gallosum, P. apiculatum e Tetragastris panamensis, mas a germinação criptocotiledonar delimita a primeira espécie das demais.

Além do tipo de germinação, $P$. apiculatum e P. gallosum são estreitamente relacionadas quanto a morfologia de plântulas, mas podem ser bem delimitadas pela margem foliar serreada na primeira espécie.

Os resultados obtidos demonstram que os padrões de germinação e a morfologia das plântulas constituem ferramentas úteis para a sistemática das Burseraceae. Os caracteres morfológicos mais relevantes para a delimitação das nove espécies de Protium foram encontrados, principalmente, na coloração, forma e superfície do fruto e pirênio, e na forma e textura dos eofilos. Além disso, o conjunto de caracteres com base na composição, margem e ápice dos eofilos, tipo de germinação e morfologia dos cotilédones não só auxiliou nas delimitações específicas, como pode subsidiar futuros estudos filogenéticos. A ampliação de estudos do desenvolvimento pós-seminal para outros gêneros da família, bem como para outros grupos de plantas permitirá um melhor conhecimento da regeneração em florestas tropicais.

\section{Referências bibliográficas}

Abreu, D. C. A.; Nogueira, A. C. \& Medeiros, A. C. S. 2005. Efeito do substrato e da temperatura na germinação de sementes de cataia (Drimys brasiliensis Miers. Winteraceae). Revista Brasileira de Sementes 27(1): 149-157.
Araújo, E.C.; Mendonça, A.V.R.; Barroso, D.G.; Lamônica, K.R. \& Silva, R.F. 2004. Caracterização morfológica de frutos, sementes e plântulas de Sesbania virgata (Cav.) Pers. Revista Brasileira de Sementes 26(1): 104-109.

Barroso, G.M.; Morim, M.P.; Peixoto, A.L. \& Ichaso, C.L.F. 1999. Frutos e Sementes: morfologia aplicada à sistemática de dicotiledôneas. Viçosa, Universidade Federal de Viçosa (UFV).

Beltrati, C.M. 1984. Morfologia e anatomia de sementes de Trichilia elegans A. Juss. (Meliaceae). Naturalia 9: 35-42.

Beltrati, C.M. 1992. Morfologia e anatomia de sementes. Instituto de Biociências, Rio Claro: UNESP, 1992. Apostila do Curso de Pós-Graduação em Ciências Biológicas, Área de Biologia Vegetal. Departamento de Botânica.

Black, G.A.; Dobzhansky, T.H. \& Pavan, C. 1950. Some attempts to esimate species diversity and population density of trees in Amazonian forests. Botanical Gazette 3(4): 413-425.

Cuatrecasas, J. 1957. Prima Flora Colombiana. I Burseraceae. Webbia. v.12, 2. p.375-441.

Daly, D.C.B. 1987. A Taxonomic revision of the genus Protium (Burseraceae) in eastern Amazonia and the Guianas. v.1-2. University Microfilms International. Tese de Doutorado. New York, Faculty in Biology.

Daly, D.C.B. 1992. New taxa and combinations in Protium Burm. f. studies in neotropical Burseraceae VI. Brittonia 44(3): 280-299.

Duke, J.A. 1965. Keys for the identification of seedlings of some proeminent woody species in eight forest types in Puerto Rico. In: Ann. Missouri Botanical Garden 52(3): 314-350.

Duke, J.A. 1969. On Tropical Seedelings. In: Ann. Missouri Botanical Garden 56(2): 125-161.

Ferraz, I.D.K.; Camargo, J.L.C.; Mesquita, M.R.; Eicher, I.; Palacios, S.; Barbosa, A.S.; Luize, B.G.; Viscarra, T. \& Pereira, B.T. 2004. Guia de Propágulos \& Plântulas da Amazônia. Manaus, Projeto Dinâmica Biológica de Fragmentos Florestais - INPA.

Killeen, T.J.; García, E.E. \& Beck, S G. 1993. Guia de Arboles de Bolivia. La Paz, Bolívia. Herbário Nacional de Bolivia/ Missouri Botanical Garden. p.170-172.

Kuniyoshi, Y.S. 1983. Morfologia da semente e da germinação de 25 espécies arbóreas de uma floresta com Araucária. Curitiba, UFP, 1983. Dissertação (Mestrado em Ciências Florestais), Setor de Ciências Agrárias, Universidade Federal do Paraná.

Lawrence, G.H.M. 1951. Taxonomia das Plantas Vasculares. Lisboa, Fundação Calouste Gulbenkian. v.2: 558-560.

Lima, M.P.M. 1985. Morfologia dos frutos e sementes dos gêneros da tribo Mimoseae (Leguminosae Mimosoideae) aplicada à Sistemática. Rodriguésia 37(62): 53-78.

Luizão, F.J. \& Vasconcelos, H.L. 2005. Floresta Tropical Úmida (Manaus) - Site 1. Disponível em: <http:// www.icb.ufmg.br/ peld/site01.html>. (Acesso em: 13/04/2005). 
Moreira, F.M.S.; Moreira, F.W. 1996. Características da germinação de sementes de 64 espécies de leguminosas florestais nativas da Amazônia em condições de viveiro. Acta Amazônica 26(1/2): 3-15.

Nee, M. 1995. Flora Preliminar do Projeto Dinâmica Biológica de Fragmentos Florestais (PDBFF). New York Botanical Garden/INPA/Smithsonian. Manaus, AM.

Oliveira, E.C. 1993. Morfologia de Plântulas. Pp. 175-213. In: I.B. Aguiar; F.C.M. Piña-Rodrigues \& M.B. Figliolia. Sementes Florestais Tropicais. Brasília, ABRATES.

Oliveira, E.C. 2001. Morfologia comparada de plântulas e plantas jovens de leguminosas arbóreas nativas: espécies de Phaseoleae, Sophoreae, Swartizieae e Tephrosieae. Revista Brasileira de Botânica 24(1): 85-97.

Radford, A.E.; Dickinson, W.C.; Massey, J.R. \& Bell, C.R. 1974. Vascular Plant Systematics. New York Harper \& Row Publishers.

Ribeiro, J.E.L.S.; Hopkins, M.J.G.; Vicentini, A.; Sothers, C.A.; Costa, M.A.S.; Brito, J.M.; Souza, M.A.D.; Martins, L.H.P.; Lohman, L.G.; Assunção, P.A.C.L.; Pereira, E.C.; Silva, C.F.; Mesquita, M.R. \& Procópio, L.C. 1999. Flora da Reserva Ducke - Guia de Identificação das Plantas vasculares de uma Floresta de terra-firme na Amazônia Central. Manaus, INPA/DFID.

Ricardi, M. 1996. Morfologia de los cotiledones de plántulas de algunas famílias o géneros presentes en Venezuela como fuente de caracteres para su determinación. Plantula 1: 1-11.
Richardson, J.E.; Pennington, R.T.; Pennington, T.D. \& Hollingsworth, P.M. 2001. Rapid diversification of a species-rich genus of Neotropical rain forest trees. Science 293: 2242-2245.

Roosmalen, M.G.M. 1985 Fruits of the Guiana Flora. Utrecht, Institute of Systematic Botany, Utrecht University and Wageningen Agricultural University.

Siqueira, J.B.G. 1991. Contribuição ao estudo fitoquímico do gênero Protium: P. tenuifolium (Engl.) Engl. e P. laxiflorum Engl. (Burseraceae). Manaus, INPA/ UFAM, 1991. Dissertação (Mestrado em Química de Produtos Naturais).

Spjut, R.W. 1994. A Systematic Treatment of Fruit Types. Memoirs of The New York Botanical Garden. The New York Botanical Garden 70: 70-93.

Susunaga, G.S. 1996. Estudo químico e biológico da resina produzida pela espécie Protium heptaphyllum March. (Burseraceae). Manaus, UFAM, 1996. Dissertação (Mestrado em Química de Produtos Naturais), Universidade Federal do Amazonas.

Vidal, W.N. \& Vidal, M.R.R. 2000. Botânica - Organografia. 4 ed. Viçosa, Editora Universidade Federal de Viçosa.

Vogel, E.F. 1983. Seedlings of dicotyledons. 2 ed. Centre for Agricultural Publishing and Documentation, Wageningen, the Netherlands. 